NBER WORKING PAPER SERIES

\title{
EMPLOYMENT, UNEMPLOYMENT AND DEMAND SHIFTS IN LOCAL LABOR MARKETS
}

Harry J. Holzer

Working Paper No. 2858

\author{
NATIONAL BUREAU OF ECONOMIC RESEARCH \\ 1050 Massachusetts Avenue \\ Cambridge, MA 02138 \\ February 1989
}

This project has been supported with a grant from the W.E. Upjohn Institute. Christine Tonnos provided valuable research assistance. I have benefited from the comments of Katherine Abraham, Dan Hamermesh, Ed Montgomery and seminar participants at Michigan State, UCLA, Santa Barbara, Berkeley, Cornell, and Northwestern. This paper is part of NBER's research program in Labor Studies. Any opinions expressed are those of the author not those of the National Bureau of Economic Research. 


\title{
EMPLOYMENT, UNEMPLOYMENT AND DEMAND SHIFTS
}

IN LOCAL LABOR MARKETS

\section{ABSTRACT}

This paper analyzes the effects of demand shifts within and between local labor markets on unemployment and employment levels and changes observed in those markets. Between-market demand shifts are measured by the means of sales growth for firms in each market, while within-market shifts are measured by variances in each. The variances are also decomposed into between-industry and within-industry components. Some firm-level evidence on job applicants, training and wage and employment adjustments in growing and declining firms is presented as we11.

The results show that demand shifts between markets account for large fractions of the observed varlation in unemployment and employment rate levels and changes across markets. Within-area shifts cause much smaller and insignificant amounts of unemployment if they are between-industry, while shifts within areas and industries (accounting for the vast majority of demand shifts across firms) have no clear effects. The results therefore suggest that the unemployment effects of demand shifts depend on adjustment costs, which appear to be greatest for shifts between markets. Nonlinearities in estimated effects and growing dispersion of unemployment rates across areas also suggest that demand shifts may have raised aggregate unemployment in the U.S. In recent years.

\author{
Harry Holzer \\ Department of Economics \\ Michigan State University \\ East Lansing, MI 48824
}




\section{Introdaction}

Labor economists have long been concerned with the problem of sorting out different kinds of unemployment. More specifically, the need to distinguish "frictional" or "structural" unemployment from that which arises due to deficient aggregate demand has critical policy importance.

One potential source of structural problems that has recently been considered involves shifts in demand across various sectors of the economy. In particular, Lilien (1982) found that the variance of employment growth rates across industries contributed to high unemployment rates in the $1970^{\prime} s$. He interpreted this as evidence of a structural unemployment problem, caused by sectoral shifts in labor demand. In contrast, Abraham and Katz (1986) found that the variance of employment growth is also correlated negatively with job vacancy rates over time (where the latter is proxied by the Conference Board's Help-Wanted Index). Their finding suggests that high variance in employment growth reflects low aggregate demand, caused perhaps by a greater sensitivity of low-growth industries to cyclical downturns. Recent papers by Rogerson (1987) and Davis (1987) have helped to keep the debate alive, and to extend it into discussions of "real business cycles" as well. 1 Furthermore, Leonard (1986, 1987), Evans (1987), and Dunne et. al. (1989) have recently analyzed variations in employment growth across firms, both within and between industries. Leonard (1987) raises the question of how such variation contributes to frictional and/or structural unemployment. He calculates some potential effects (based on assumptions regarding average tumover and unemployment durations), but no direct evidence is provided.

In this paper I analyze the relationship between unemployment/employment outcomes and sales growth variation within and between local labor markets. More specifically, we use sales growth measures at the 
flrm level to calculate varlous measures of product and/or labor demand shifts which are then used to explain \& varlety of employment outcomes in local labor markets.

Unifke the papers mentioned above, the focus here is on differences in local unemployment and employment growth tates at a point in time rather thar aggregate rates over time. The study of demand shifts between areas thus buidis on that of Topel (1986), among others. ${ }^{2}$ Given the use of firm-level data within these areas, several types of shifts can be considered here. They inciude: ij shifts in demand between local labor naricets; 2) shifts its demard within locai markets but between industries; and 3 shifts within loca markets and winfn industries

The dffferent types of shifts might have very different implications for employment and unemployment, since the costs of labor market adjustment to these shifts should differ as weli. For instance, the costs of worker migration in response to shifts between markets may be substantially greater than adjustment costs to shifts within markets. Also, shifts between industries may involve greatez adjustment costs than those within, if industry-specific sk111s are fmportant and costlier to replace than are firmspecific ones. Search costs across areas and industries may also be higher than those within them. The relative magnitudes of the employment and unemployment effects for different types of shifts should thus enable us to determine where the costs of adjustment are greatest. 3

The sales growth data used to calculate these shifts are from the Employment Opportunity P1lot Project (EOPP) Survey of Firms in 1980 and 1982. This sample of about 3400 firms represents 28 local labor market sites at which the EOPP experiments vere being run. ${ }^{4}$ of these, thirteen are in SMSA's and the rest are groups of counties. 5 
The analysis below begins with data at the firm-level and then proceeds to consider data at the level of the local labor market. The firm-level analysis includes a comparison of job applicant rates, training, and employment and wage adjustments at firms with growing and declining sales. We then compute aggregated measures of sales and employment growth at the site level and merge them with published Census data on unemployment rates and various industrial and demographic characteristics. We use differences in mean sales growth across local areas to measure shifts in labor demand between local markets and variances to measure shifts within these markets. The latter are also decomposed into between-industry and within-industry components. The effects of these shift measures on unemployment and employment growth levels and across areas are then estimated.

Because of some limitations on the size and representativeness of the EOPP sites, we also perform a similar analysis using Census of Industry data across states from 1972, 1977, and 1982. Real sales growth measures at the Industry level and a variety of employment and unemployment data for each state are used in this part of the analysis.

The results of this study can be briefly summarized here. We find that demand shifts across local markets are negatively related to unemployment rates and positively to employment growth rates, thereby indicating major employment effects of demand shifts between areas. Though only a small part of the total variation in sales growth across firms, these differences explain fairly large fractions of the total variation in unemployment and employment rates and changes across areas. Within-area demand shifts have small and generally insignificant positive effects on unemployment and negative effects on employment if they are shifts between industries, while those within industries (accounting for most of the sales growth variation) have no clear 
effects. The results therefore siggest that the unemployment effects of demand shifts are high only when adjustments involve costly migration be cween merkets. Wage riglditles which are observed at declining firms and training needs at growing ones might also contrlbute to these effects. Finally, estimated nonlinearities in employment effects and rising dispersion in unemployment across areas also suggest that demand shifts may have rafsed aggregate unemployment in the U.S. in recent years.

The rest of the paper is outlined as follows: Section II contains a longer description of the data and some micro evidence on growth in sales, employment, and wages (among other characteristics) across firms. Section III presents evidence at the local market level from the EOpP data, while Section IV presents similar results using Census of Industry data. Section V concludes the paper.

\section{Data and Micro-Level Evidence on Sales and Buployent Groth}

The 1982 follow-up to the EOPP Survey of Firms asked the following questions: "After adjusting for price changes in your product, were your unit sales in 1981 hIgher, lower or about the same as in $1979 ?$ Approximately what was the percentage change?" It is this variable that will be used to measure sales grow th across firms.

We can also calculate employment and wage growth at the firm for these years. Both the 1980 and 1982 surveys also asked for the number of full-time and part-time employees in the flrms. In the 1980 survey this question was asked for the current time (1.e., at the time of the survey) as well as for July and December of 1979. In the 1982 survey employment slze was also gauged for the current tIme and for July and December of 1980 and 1981 . UsIng the employment figures for December of 1979 and 1981 , it is therefore possible to 
calculate employment growth rates during the same period as that used for sales growth. As for wage growth, firms were agked for their average percentage Increase in wages between 1979 and 1981.

A few words are in order regarding the interpretation of sales growth as a measure of labor demand shift. Differences in sales growth across firms presumably reflect differences in output growth, assuming that inventorieg adjust relatively quickly to their equilibrium levels. Output changes can reflect shifts on the supply-side or demand-side of the product market, where the former might be caused by changes in technology and/or relative factor prices. Exogenous changes in output prices, such as occurred for the oll and petrochemical industries during the ofl shocks of the $1970^{\prime} \mathrm{s}$, can also result in these changes.

All of these forces will create shifts in labor demand through the standard "scale effects" on employment which move in the same direction as the output change. While changes in other factor prices can also have "substitution effects" on labor demand, these would generally move in the opposite direction from the output changes. Thus we can infer the relative importance of these effects from the sign of the correlation between sales growth and employment or unemployment; if sales growth and employment growth are positively correlated (or sales growth and unemployment are negatively correlated), then the "scale effects" dominate and the labor demand-shift interpretation is correct.

Labor supply shifts and/or exogenous wage changes can also result in changes in sales growth and unemployment, both of which would therefore be endogenous. But the correlation between sales and wage growth must be negative in order for exogenous labor supply shifts or wage changes (1.e., those which do not occur in response to demand shifts) to be the cause of the observed results. In fact, the positive correlations observed below between 
sales, wage, and employment grow th across firms (as well as postefve correlations of sales growth with vacancies) confirm that sales growth does, In fact, reflect exogenous shifts in labor demand.

In Table I we present some evidence on sales growth at the firm level. In addition to the mean and standard deviation of this measure we present the fractions of the total varlation of the log of ( $1+\%$ sales growth) that are explained by varfous groups of industry and/or site dummies. These fractions represent the "between-1ndustry" and "between-area" components of that variation. The fractions are measured by the $R^{2}$ and adjusted $R^{2}$ measures for regression equations containing the site and industry varlables. The Fstatistics for those sets of dummies are also presented to test for the joint significance of the between-industry and between-area effects.

The results of Table 1 contaln two basic findings. On the one hand, the F-statistics tell us that the industry and area differences in sales growth are signiflcant. All of the sets of dummies are signiflcant at the .05 level except for the interaction effects after site and industry are already included ( the critical value here is about 1.1). The marginal F-values show us that industry differences are significant within areas and area effects are significant within industries. Thus nefther set of different effects fully account for the other.

On the other hand, the between-area and Industry effects (Including interactions) together explain only very small fractions of the total varlation in sales growth across firms. This implies that the vast majority of sales growth variation is within-area and within-industry. This may partly reflect some measurement-error in the sales growth measure or random "nofse" In the data. But these results are consistent with those of Leonard (1987) and Dunne et. al. (1989) who find that most of the variation of employment grow th at the firm-level is whthin-area and industry. 


\section{Table 1}

Sales Growth Across Firms:

Between-Industry and Between-Site Varlation

Mean (S.D.) $\quad \begin{gathered}.031 \\ .050\end{gathered}$

of $\log (1+\%$ sales growth)

Explana tory

Varlables:

\begin{tabular}{|c|c|c|c|c|c|}
\hline 1) & $\begin{array}{l}1-d 1 g \text { It industry } \\
\text { dummies }\end{array}$ & .017 & .017 & 4.57 & - \\
\hline 2) & $\begin{array}{l}\text { 2-diglt Industry } \\
\text { dummies }\end{array}$ & .037 & .020 & 2.20 & - \\
\hline 3) & Site Dummies & .036 & .024 & 2.86 & - \\
\hline 4) & $\begin{array}{r}\text { 1-digit industry } \\
+ \text { site dummies }\end{array}$ & .053 & .037 & 3.27 & $\begin{array}{l}2.55^{\mathrm{a}} \\
4.43^{\mathrm{b}}\end{array}$ \\
\hline 5) & $\begin{array}{r}2-d 1 g 1 t \text { Industry } \\
+ \text { site dummies }\end{array}$ & .072 & .043 & 2.47 & $\begin{array}{l}2.48^{\mathrm{a}} \\
1.87^{\mathrm{b}}\end{array}$ \\
\hline 6) & $\begin{array}{l}\text { Site, l-digit } \\
\text { industry, and } \\
\text { interaction dummies }\end{array}$ & .163 & .063 & 1.64 & $.99^{c}$ \\
\hline
\end{tabular}

$\underline{\mathrm{R}^{2}}$

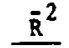

Total

4.57

interaction dummies

Notes:

a After site dummies already included.

b After industry dummies al ready included.

c After site and 1-digit industry dummles already included. 
Before we move on to consider the effects of these different types of output shifts on local unemployment rates, it seems worthohile to consider a b1t more evidence on firm-level responses to these shifts. In Table 2 we consider several characteristics of firms with elther growing or declining sales: namely, thelr wage and employment growth as well as applicant rates and training levels for new positions. These results should help to shed light on the characteristics and responses of firms facing positive and negative demand shifts.

For Instance, comparisons of employment growth across the two sectors (and especially their respective responses to unit changes in sales growth) show us whether employment grow th at growing firms is more sluggish than decreases at declining firms. This, in fact, would be the case if adjustment costs are serlous problems (see Footnote 3). Wage growth comparisons show us the extent to which downward wage rigidity at declining flrms may further 1mpede the adjustment process by ralsing the magnitudes of employment declines and perhaps by encouraging queuing for the more limited number of jobs in that sector. In fact, we can use applicant levels for new positions as a proxy for worker queues facing each type of firm. Furthermore, the amounts of training provided to newly hired workers provide a rough measure of necessary sk111 attalnments which might 1mpede adjustment as well if they are higher in the growling sectors.

We present two types of data in Table 2. The first includes means for each of these variables for firms with growing and with declining sales (zero growth firms are included in the latter). The second includes coefficlents from regressions in which wage and employment growth appear as dependent varlables and sales growth appears as the independent varlable. These equations measure the responsiveness of wages and employment in firms facing positive and negative demand shifts. 
As noted above, the employment and wage grow th varlables reflect the 1979-81 period (as does sales growth) and are measured as the log of ( $1+$ the growth rate). Training is measured by the hours of formal and informal training provided to the most recently hired employee of the $\mathrm{f} 1 \mathrm{rm}$, while applicant queues are measured as applicants for the job of the last person h1red.

The means of Part A In Table 2 suggest several interesting features of growling and declining firms. Employment and wage growth are signiflcanty higher for firms with growing sales than for those with decilning sales, though the difference in wage growth over two years in only about two percent. ${ }^{6}$ Hours of formal and informal training are both higher for growing firms, though only the informal training difference is significant. These differences suggest greater training or sklli requirements (and perhaps more Inelastic supplies of labor) for growing firms in the short-run. ${ }^{7}$ But as for applicants we find no signiflcant differences in worker queues per avallable job between sectors.

Furthermore, the regression results of Part B show falrly comparable employment responses to unit differences in sales growth within each sector. In other words, we see no tendency for employment growth to be more slugglsh In growing firms overall. This suggests that, if employment adjustment problems do exist, they may be IImited to shifts across specific types or groups of firms (e.g., those across areas) and are not a more general phenomenon. Finally, the wage growth regressions show significant responsiveness to sales growth varlation in the growing firms but not the declining ones, thus providing some evidence of wage rigldity within the group of firms facing declining sales. ${ }^{8}$

Overall, then, the $f 1 \mathrm{rm}-\mathrm{level}$ data suggest the presence of significant demand shifts between areas and Industrles, though most demand shifts are 


\section{Table 2}

\section{Wage Growth, Employment Growth, Applicants and Training in Sectors With Growing and Declining Sales}

Firms with:

\section{Growing Sales}

\section{Declining Sales}

A. Means (S.E.)

$\log (1+\%$ Employment

.112

$-.040$

Grow th)

$\log (1+\%$ wage

$(.017)$

$(.016)$

Grow th)

.167

.148

$(.004)$

Hours of Training

Forma 1

12.18

10.030

$(5.230)$

Informa 1

58.373

(3.442)

48.452

$(2.514)$

Job Applicants

For Last Worker HIred

B. Effects of Changes in

$\log (1+\%$ Sales Growth) On: $\log _{\text {Grow th })}(1+7$ Employment

.424

$(.094)$

.361

$\log (1+\%$ Wage Grow th)

Note:

Standard errors appear in parentheses under regression coefficients in the second half of the table. Sample sizes are 902 for declining sales and 1186 for growing firms. Variable definitions appear in the text. 
within both. While at least some evidence of wage rigidity appears in firms with declining sales as well as higher amounts of training for those with growing sales, we find employment responsiveness across firms within the growing sales sector to be slgniflcant and generally comparable to that in the declining sales sector. The implications of these varied demand shifts and firm responses for employment and unemployment rates in local labor markets need now to be considered.

\section{Sales Growth and Onemployeent/Buplogent Effects at the Site Level}

In this section of the paper we analyze the relationship between sales growth, unemployment and employment growth at the local labor market level. Firm-level data on sales and employment growth are aggregated to the s1te level, of which there are 28 in the EOPP data. These data are then merged with Census data on unemployment rates and other labor market characteristics for the same areas.

In aggregating sales growth measures to the site-level, we have sampleweighted and firm size-weighted these measures. Sample-weighting is used to counteract the oversampling in the EOPP survey of large, low-wage firms within each site. Sampling weights thus create a random sample of firms within each site. Size-welghting is then used to generate measures which accurately reflect the labor force in each local market.

In analyzing these data we will consider both the means and variances of growth rates for each market. Differences in means of sales growth can be interpreted as between-market shifts in demand while variances are interpreted as within-market shifts. The latter is consistent with the interpretation given by Lilien and Abraham and Katz to varlances in employment growth across 
industrles, though here the varfances are within the local market. In contrast, the means measure differences in the total level of demand growth which the local market faces.

In addition, the varlance measures are then decomposed into betweenIndustry and within-industry shffts across firms in each local area. This is accomplished by using separate firm-level regressions of log sales grow th at each site on a set of I-diglt industry dummies. Since the adjusted $\mathrm{R}^{2}$ for each equation gives us the fraction of the total varfation in sales growth that is explained by differences between industrles, we use the following formula:

$$
\sigma_{T, 1}^{2}=\sigma_{B, 1}^{2}+\sigma_{W, 1}^{2}=\bar{R}_{1}^{2} \sigma_{T, 1}^{2}+\left(1-\bar{R}_{1}^{2}\right) \sigma_{T, 1}^{2}
$$

where $\sigma_{T, 1}^{2}$ is the total (welghted) varlance in the log of sales growth in the 1 th local market and $\sigma_{B, 1}^{2}$ and $\sigma_{W, 1}^{2}$ are the between Industry and withinindustry components respectively. 9

In Table $3 A$ we turn to estimates of the effects of sales growth on unemployment rates and in Table $3 B$ we have estimates of their effects on employment growth across local markets. We have estimated the following equations:

$$
\begin{aligned}
& U_{1}=a_{U}+b_{U} \mu_{1}+c_{U} \sigma_{B, 1}^{2}+d_{U} \sigma_{W, 1}^{2}+f_{U} X+\varepsilon_{u, 1} \\
& \dot{E}_{1}=a_{E}+b_{E} \mu_{1}+c_{E} \sigma_{B, 1}^{2}+d_{E} \sigma_{W, 1}^{2}+f_{E} X+\varepsilon_{E, 1}
\end{aligned}
$$

where $U_{1}$ and $\dot{E}_{1}$ are unemployment and employment grow th rates for the 1 th market; $\mu$ is the sample- and size-weighted mean of ( 1 + real sales growth) for each site; and $x$ is a set of controls described below. 


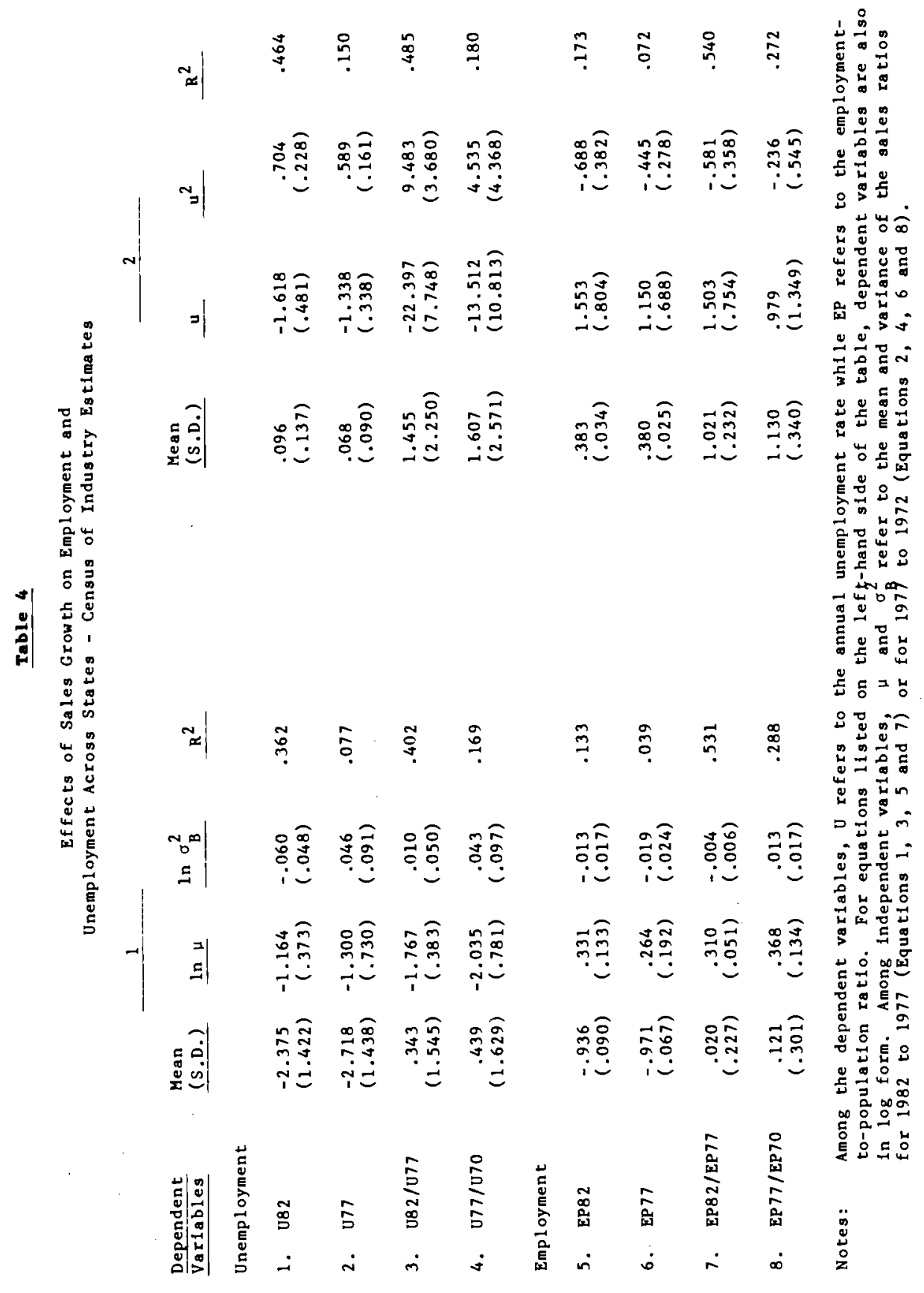




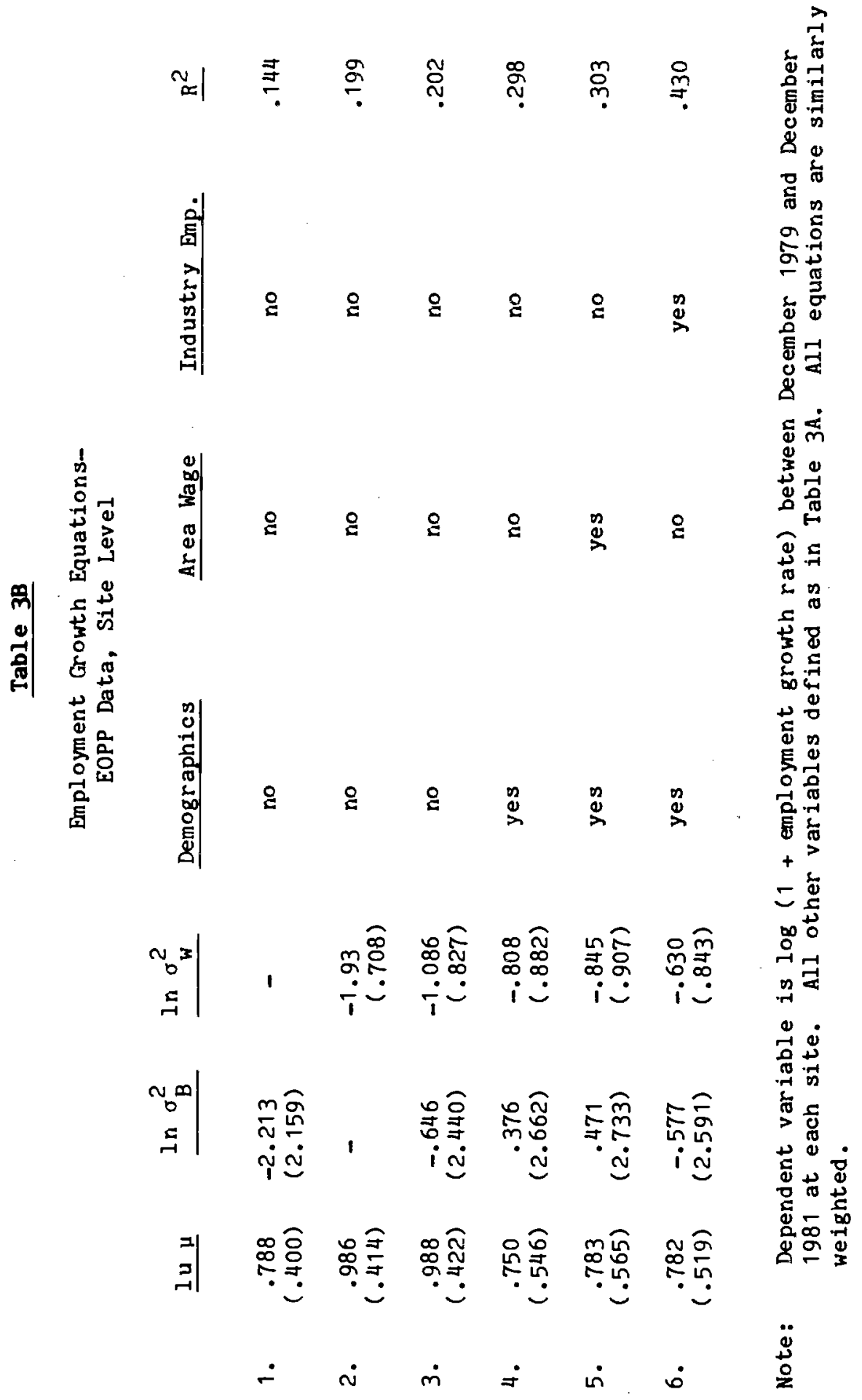


Employment growth rates are firm-size and sample-weighted means calculated from the 1982 EOPP Survey. (where employment growth is again measured from December 1979 to December 1981). The unemployment rates are published rates based on the 1980 census. Clearly, we would prefer that the dependent variables in both equations be measured as changes rather than levels. But we focus on unemployment rate levels in 1980 since they are not avallable for non-SMSA sites in 1979 or 1981 . This focus 1s, however, consistent with that of Lilien and of Abraham and Katz, who estimated unemployment rate equations; and also with the standard "Okun's Law" estimates of output growth effects on unemployment rates. When analyzing census of Industry data below, we will consider sales growth effects on both levels and changes of unemployment rates.

All equations are estimated using Weighted Least Squares, where the weights are (labor force size) $1 / 2.10$ Both dependent and independent varlables appear in $\log$ form. 11 In some specifications, we use each component of $\sigma_{\mathrm{T}, 1}^{2}$ separately, due to thelr high coorelations $(r=.66)$.

The control variables include the following: 1) the $\log$ of the unemployment rate for $1970\left(U_{70}\right)$, which should capture a long-run equilibrium component of local unemployment; 2) a variety of demographic and financial variables, which include: a) the ratio of average weekly Unemployment Insurance benefits to weekly wages in the state b) the fraction of the population aged 25 and over with college degrees; c) the log of the median age of the labor force; and d) the fraction female in the labor force; 3) the average wage premium of firms in the local market; and 4) the fractions of employed individuals who work in the manufacturing and service sectors.

The UI, average wage and demographic variables are designed to control for determinants of "equilibrium" unemployment across areas (e.g., Hall (1970)), while industry employment might capture both cyclical and equilibrium 
components (through differences in wages, turnover, etc, as well as the different cyclical sensitivities of these industries).

The 1970 unemployment rates and the educational, labor force and industrial distributions are published Census data, while the statewide ratios appear in Department of Labor publieations. The wage premiun is calculated from the EOPP Survey of Firms in 1980 , and represents a weighted meari of residuals from a log wage equation on various human capital characteristics in each site. 12

The results of Table $3 A$ show that mean growth rates fn sales have significantly negative effects on unemployment rate levels. Estimates of elasticities are approximately 3.0-3.5. Comparisons with roughly similar estimates computed at the aggregate level suggest that these are reasonable estimates. ${ }^{13}$ For the total sample, a standard deviation change in sales growth generates a change in log unemployment rate levels of about three quarters of a standard deviation. 14 In fact, the estimated $R^{2}$ for these equations suggest that mean sales growth explains about $60 \%$ of the total variation in unemployment rates across all sites. Adding a variety of control variables reduces the mean sales growth effect by only a small amount.

As for variance of sales growth, we find positive but insignificant effects of the between-industry component on unemployment rates. A onestandard-deviation rise in between-industry variance raises unemployment rates by less than $10 \%$ of a standard deviation. In contrast, the within-industry component of variance appears to have negative but insignificant effects on unemployment.

The employment growth equations of Table $3 B$ show results that are consistent with those of Table $3 \mathrm{~A}$. Mean sales growth effects on employment growth are positive and generally significant, with elasticities in the region of .8-1.0. Both between- and within-industry components of variance generally 
reduce employment growth, but once again these effects are not significant and are sensitive to the inclusion of control variables. The explanatory power of these equations are lower than those of the unemployment equations, due perhaps to greater measurement error in the employment growth variable (based on EOPP rather than Census data).

It thus appears as though the small fraction of demand shifts across firms which occurs between local labor markets generally has large employment and unemployment effects while shifts within local markets create much less. There is some evidence of structural-type unemployment and employment problems caused by shifts that occur between industries and within areas, though the estimated effects are generally insignificant and relatively small in magni tude.

These results therefore confirm our earlier conjectures about the relative costs of labor market adjustment in response to different types of demand shift. Adjustments to shifts between local markets appears to be costlier than adjustments within markets. Those costs and responses manifest themselves in unemployment rate differences across areas which may persist for several years. 15

A number of important points must be mentioned regarding these findings. For one thing, it is possible that the sales growth effects on employment and unemployment primarily reflect the different sensitivities of local areas to the business cycle of 1981-2 (which should be partly captured by sales growth in 1979-81). However, it is unlikely that the cycle explains the entire effect. Unemployment rates for 1980 are not heavily influenced by the cycle, ${ }^{16}$ and industry control varlables do not greatly reduce the magnitudes of estimated effects.

Another possible problem with these results is the potential endogeneity of the sales growth measure with respect to employment or 
unemployment. Exogenous population or labor force changes could directly affect employment or unemployment and thereby lead to sales growth changes. But the negative effect of sales growth on unemployment makes this interpretation unlikely, since exogenous population or labor force changes which raise sales growth should also raise unemployment rates. The positive correlations between sales growth, vacancy rates and wage growth (as well as employment growth) at the site level all suggest that sales growth differences reflect exogenous shifts in labor demand. ${ }^{17}$

We also note that the functional forms of these estimated relationships are important determinants of aggregate changes in employment and unemployment caused by demand shifts. If employment changes in growing areas are smaller than those in declining areas, this would be reflected in a quadratic (or other convex) function. ${ }^{18}$ Such a function would indicate that rising dispersion in sales growth (which could be caused by shifts from declining to growing areas) would result in lower aggregate employment or higher unemployment. 19 It would also suggest that employment adjustment problems for growing areas may be greater than they are for growing firms (since there was no evidence of employment adjustment problems in the sample of all growing firms in the previous section).

The results of estimated equations containing quadratic terms in sales growth show the correct signs on coefficients for these terms, though they are generally not significant. ${ }^{20}$ More evidence on these functional forms is provided below.

Finally, we note that labor demand shifts across areas should only cause employment growth and unemployment rate changes in the short-run. Eventually, wage and price adjustments as well as migration should reequilibrate these markets (Tope1, 1986). In fact, the positive correlation between sales growth, employment growth and wage growth described above 
confirms this. There is also some evidence of migration towards growing areas and away from declining ones. 21 However, these adjustments do not appear to occur quickly enough to eliminate the effects of sales growth on employment and unemployment in the short-run.

\section{Census of Industry Resalts}

The EOPP Survey has the advantage of providing micro-level firm data from which we could calculate within and between industry variances in real sales growth and analyze their effects on unemployment and employment growth.

But the small number and non-random nature of the EOPP sites raise some questions about these results. Potential births and deaths of firms within the sample are also a problem. We therefore turn to the U.S. Census of Industry for additional evidence.

For each state, we have calculated employment-welghted means and variances (between-industries) of real sales growth for 1972-77 and for 197782. The Industries included are those for whlch Census data are avallablei.e., agriculture, durable and nondurable manufacturing, construction, mining, wholesale and retall trade, services, and government. Nominal sales in each year were measured by the value of shipments (mining and manufacturing), recelpts (construction and services), sales (agriculture, wholesale and retall trades), and direct expenditures (government). These nominal values are deflated by GNP Industry deflators, though simllar results have also been obtalned using a combination of PPI and other GNP deflators. ${ }^{22}$

The means and varlances of $1+$ the real sales growth rate (or the ratios of values for 1982 to 1977 and 1977 to 1972) are used as Independent varlables. Dependent variables include unemployment rates and employment-topopulation ratios in 1977 and 1982 as well as changes (or ratios) in 


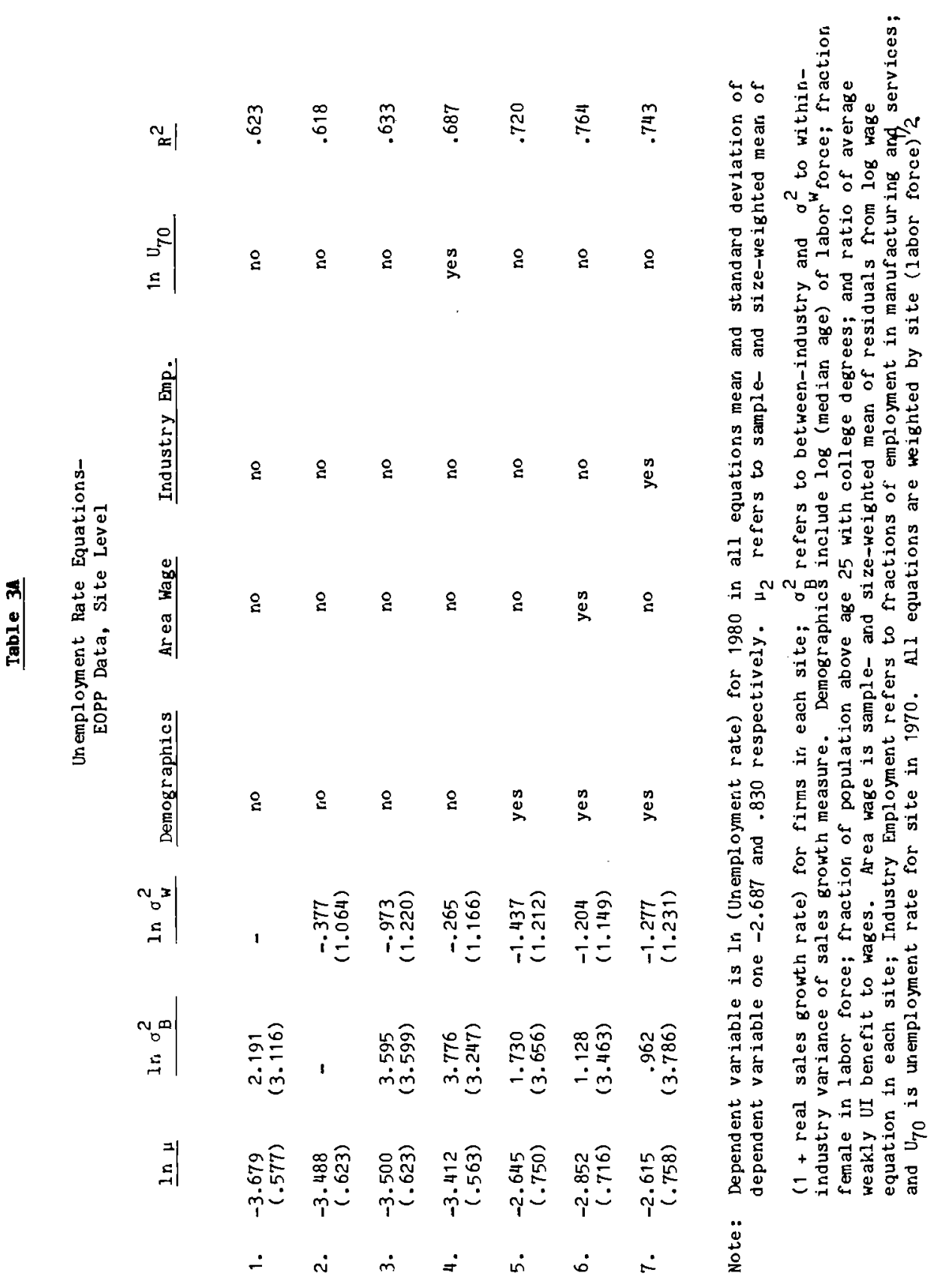


unemployment rates and employment rates for $1972-77$ and $1977-82.23$ The two sample periods enable us to check for whether or not cyclical effects dominate the results for the early $1980^{\prime}$ s. $^{24}$ All equations are weighted by (state emp loymen $t)^{1 / 2}$

The results for these estimated equations appear in Table 4. Two functional forms are presented: logarithmic and quadratic. The logs of the levels and the ratios (i.e., levels and differences of logs) are thus compatable to the measures used with the EOPP data above. But the quadratic case here, variances are omitted from the equations due to their high correlations with the means. 25

Unemployment rates for 1970 are used as the base year for changes in the earlier pertod, since published annual averages by sate are not avallable before 1975. The employment rates are based on household rather than establishment data, since the latter omit agricultural employment (that may be empirically important in various states). We also focus on employment-topopulation ratios rather than overall employment, since sales (or output) growth is more likely endogenous with respect to population grow than to growth in employment out of the population. However, most results discussed below hold for both measures.

A number of results appear in Table 4 which are quite comparable to those presented above for the EOPP data. For one thing, mean sales growth has large and significant negative effects on unemployment and postive ones on employment. This is true for both levels and changes. Judging by $\mathrm{R}^{2}$, we generally find that sales growth has greater explanatory power for changes than for levels. In fact, about $40 \%$ of the variation in unemployment changes and over $50 \%$ of that for employment changes are explained by these equations for the 1977-82 period. 
The effects for this period are obviously much larger than those for 1972-77. At least partly (though perhaps not exclusively) this must reflect the business cycle in the later period. The very comparable results between unemployment rate equations for 1980 and 1982 also suggest that the business cycle does not account for the entire difference between the two periods. Explanatory power for either of these equations is a bit lower than for comparable equations using the EOPP data.

The effects of between-industry variances in sales growth are generally positive for unemployment and negative for employment, as would be expected from a model in which such shifts are costly. However, these effects are not significant in any equation.

The quadratic terms in the second set of equations show positive coefficients for unemployment and negative ones for employment. Most are significant by conventional standards, though this is less true for ratios in the earlier period. Comparable results are also obtained from segmented linear equations, estimated for positive and negative sales growth in the later period. 26 As noted above, these effects imply that greater dispersion across areas in sales growth will produce not only greater dispersion in but also higher (lower) aggregate unemployment (employment). In fact, dispersion in sales growth was higher for the 1977-82 period than for the 1972-77, and dispersion in unemployment rates grew consistently between 1970 and 1982.27 These results therefore suggest that demand shifts across areas may have helped raise aggregate unemployment rates in the U.S. In the $1980^{\prime} \mathrm{s}$.

A few other points should be mentioned here as well. For one thing, we have estimated equations comparable to those of Summers (1986) and Murphy and Topel (1987) in which sales growth is considered separately for high-wage and low-wage industries as well as for manufacturing and non-manufacturing. While results are sometimes stronger for the high-wage and manufacturing cases, the 
others are generally significant as well. ${ }^{28}$ A variety of other estimates, using the different sets of price indices and both with and without the government sector, produced comparable results to those of Table 4. Finally, equations containing lagged and lead terms suggest that the endogeneity of sales grow th with respect to the employment or unemployment rates used here may not be too severe. ${ }^{29}$ Consequently, the results presented using Census of Industry data largely confirm our findings obtained from the EOPP data and described above.

\section{v. Conclusion}

In this paper I analyze the relationship between unemployment rates and demand shifts in local labor markets. Three types of demand shifts are distinguished here: 1) Those between local labor markets; 2) those within local markets but between industries; and 3) those within local markets and within industries. The first of these is measured by differences in mean sales growth of firms in various local labor markets while the second and third are measured by components of the varlances across firms in each market. Some firm-level evidence on job applicants, training, and wage and employment adjustments in growing and declining firms is presented as well. The estimated results show that demand shifts between local markets, which account for only a very small fraction of sales growth varlation across firms, have very substantial impacts on observed unemployment and employment growth rates. Shifts within local markets appear to have much smaller effects on unemployment, with only those between industries showing some small but generally insignificant positive effects. The estimated unemployment effects continue to hold after controling for a variety of factors which should reflect "equilibrium" or cyclical differences in unemployment rates. The 
results thus suggest that the unemployment effects of demand shifts are high only when adjustments involve costly migration between markets. The observed wage rigidities at declining firms and training needs in growing ones may also contribute to these results in some cases.

Finally, estimated nonlinearities in the effects of sales growth on employment across local areas and evidence of rising dispersion in local unemployment rates suggest that aggregate unemployment have risen as a result of demand shifts in the late $1970^{\prime} \mathrm{s}$ and $1980^{\prime} \mathrm{s}$. This last finding suggests that greater discussion of policies which lower adjustment costs or uncertainties for workers (e.g., government subsidies for worker relocation, greater provision of information on job vacancies in local markets, etc.) is warranted at this time.

\section{FOOTNOTES}

IThe Iiterature which stresses sectoral shocks as potential

explanations for observed aggregate movements in output and employment dates back to Lucas and Prescott (1974). More recent examples include Long and Plosser (1983).

${ }^{2}$ While several authors have analyzed the response of local unemployment rates to aggregate demand shifts (e.g., Browne (1978), Murphy and Hofler (1985), Rones (1986)), there have been no studies which provide direct evidences on shifts between and within local areas for the U.S. AItonji and Ham (1986) do, however, consider the role of aggregate, industry and provincial demand shifts on employment growth in Canadian provinces. 
${ }^{3}$ These issues could easily be analyzed within the simple labor supply and demand shift model of Freeman (1977), in which the adjustment costs would lower labor supply elasticities for firms facing positive shifts. In such a model, wage rigidities and/or queulng for jobs in the declining-demand sector would further limit employment adjustments. Topel (1986) presents a model of demand shocks and migration which allows for expectations, migration costs, and different age cohorts and time periods across labor markets.

${ }^{4}$ While about 5200 firms were part of the original sample in 1980, only about two-thirds were interviewed again in 1982 .

${ }^{5}$ The SMSA's are: Cinncinat1, Columbus, Dayton, and Toledo in Ohio; Baton Rouge, Lake Charles, and New Orleans in Loulsiana; Birmingham and Mobile In Alabama; Corpus Christi; San Antonio, and Beaumont/Port Arthur in Texas;

and Pensacola, Florida. Non-SMSA sites are groups of counties in Kentucky, Virginia, Colorado, Missouri, Washington and Wisconsin.

${ }^{6}$ The standard error on the difference between means is the square root of sum of squared standard errors. The standard error on differences in employment growth is thus .023 , while that for wage growth is .005 .

${ }^{7}$ If firm-specific and general human capital are complementary, then hiring difficulties may occur for firms providing the specific training. In the absence of such complementarity, the costs and time needed for on-the-job training may still impede employment adjustment for growing firms.

${ }^{8}$ Results of these regressions do not change when site and industry dummies are included.

${ }^{9}$ The use of adjusted rather than actual $\mathrm{R}^{2}$ here reflects the problem of small sample sizes in certain sites. Sample sizes range from about 60 to 300 across sites. The adjusted $R^{2}$ "corrects" for these sample size differences, since a fixed number of independent varlables will otherwise have relatively greater explanatory power in smaller samples than in larger ones. However, the use of adjusted $R^{2}$ results in negative between-1ndustry variances being 
reported in certain cases.

${ }^{10}$ Weighting by labor force size assumes that errors are directly proportional to such size. The weighting should therefore limit problems of heteroscedasticity caused by markets of different size.

${ }^{11}$ The employement growth variables are thus measured as differences in logs of employment. The variances are actually measured as $\log \left(1+\sigma_{B}^{2}\right)$ and $\log \left(1+\sigma_{W}^{2}\right)$, since some of the $\sigma_{B}^{2}$ were based on negative adjusted $R^{2}$ and wer? therefore negative themselves. The logarithmic function along with this adjustment did not qualitatively change any results.

12 All variables except for the UI measures were calculated from countylevel data in the City and Country Data Book (1983). The UI data appear in the Department of Labor's Employment and Training Handbook No. 394 (1983).

${ }^{13}$ Estimates of "Okun's Law" relate percentage point changes in unemployment to percent changes in the ratio of actual to potential GNP. Recent estimates (e.g., Gordon (1982)) of this relationship are in the .4-.5 range. These suggest elasticities of unemployment with respect to output of about 5-7.

${ }^{14}$ A standard deviation change in the $\log$ of sales growth is weighted in the same manner as the regressions is . 18 while that for the log of unemployment is .83 .

${ }^{15}$ Adjustment speeds to regional demand shifts and unemployment are considered in Marston (1985) and Tiller and Bednarzik (1985). Marston uses a recursive error components model and calculates very rapid adjustments (i.e., within one year). Tiller and Bednarzik, using spectral methods, find much lengthier adjustment periods.

${ }^{16}$ Aggregate unemployment for 1980 averaged approximately $7 \%$ for the year.

${ }^{17}$ The correlation between sales growth and vacancy rates (both in $10 \mathrm{~g}$ 
form) at the site level is .45 .

${ }^{18}$ The 1ssue of non-11near functions in a cross-section is related to that of partial adjustments in time-series employment change equations (e.g., N1ckell (1986)). However, the partial adjustment models assume that adfustment in elther direction is costly, while the quadratics imply an asymmetry between costs for growing and declining firms.

${ }^{19}$ Evidence of rising dispersion in state-wide unemployment rates appears In Abraham (1987). She uses estimates of quadratic Beveridge Curves (1.e., unemployment-vacancy relationsh1p) to argue that shifts across areas helped ralse aggregate unemployment in the $1970^{\prime} \mathrm{s}$ and $1980^{\prime} \mathrm{s}$. On the other hand, the evidence of rising dispersion 1n uenmployment is disputed 1n Murphy (1985). Finding such a quadratic effect of sales growth on employment or unemployment would also be equivalent to finding a positive effect of the variance of sales growth across local markets on aggregate unemployment rates In time-series data (1f it were avallable for sales growth).

${ }^{20}$ The coefficlent and standard errors on the quadratic sales growth term in the unemployment equation are .523 and .597 respectively. For employment growth equations the comparable numbers are -4.79 and 5.77 .

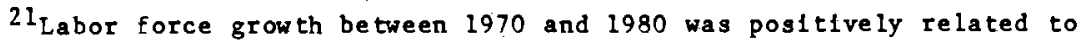
sales growth, whlle median age of the labor force was negatively related (both effects significant). Assuming younger workers migrate more frequently than older ones, both findings suggest migration to growing areas.

${ }^{22}$ In these alternative estimates, PPI deflators are used for manufacturing and mining while GNP deflators for the farm and government sectors, goods, and services are used elsewhere. Estimated results using the alternative measures were very simflar. Of course, both sets of deflators abstract from industry-specific variation in inflation across areas. 
${ }^{23}$ The relevant annula 1 averages for states are published in various issues of Employment and Earnings and in the State and Metropolitan Area Data Books.

${ }^{24}$ The mid-1970's recession is not as much of a problem for the earlier period as is the 1981-2 recession for the later period, since the economy had significantly recovered by 1977 . Aggregate unemployment rates were $5.5 \%$ in $1972,6.9 \%$ in 1977 , and $9.5 \%$ in 1982 .

${ }^{25}$ The correlation between means and variances (in logs) across states is .61 for 1977-82 and .70 for 1972-77.

${ }^{26}$ Sales growth was positive for all areas during the 1972-77 period. ${ }^{27}$ The standard deviation of sales growth across states (weighted by employment 1977) was .072 for 1972-77 and .100 for 1977-82. Standard deviations in unemployment rates across rates were $.011, .015$, and .022 for 1970,1977 , and 1982 respectively.

${ }^{28}$ Sales growth in high-wage industries generally had larger effects on unemployment rates and changes in both periods, but for employment-topopulation ratios the evidence is more mixed. Effects of manufacturing one generally lower than those for non-manufacturing, though those clearly may reflect differences in sector size. The correlations between sales growth in manufacturing and non-manufacturing are .574 for the early period and .808 for the later one.

${ }^{29}$ Unemployment equations for 1970 and 1977 which contained lead sales growth measures for 1972-77 and 1977-82 respectively generally produced incorrect signs on estimated coefficients. In contrast, equations containing lagged sales growth measures (e.g., 1972-77 sales growth in equations for 1982 unemployment rates) generally had correct signs, though with substantially smaller coefficients than on the more contemporaneous sales growth measures. 


\section{REFEREIUCES}

Abraham, Katherine. "Help-Wanted Advertising, Job Vacancles, and Unemployment," Brook1ngs Papers on Economic Act1vity, 1987:1.

Abraham, Katherine and Lawrence Katz. "Cyclical Unemployment: Sectoral Shifts on Aggregate Disturbances?" Journal of Polftical Economy, June, 1986.

Altonj1, Joseph and John Ham. "Varlation In Employment Growth In Canada: The Role of External, National, Reglonal and Industrial Factors." NBER Work1ng Paper No. 1816, January 1986.

Becker, Gary. Human Capltal. National Bureau of Economic Research, 2nd Edition, 1975 .

Browne, Lynn. "Reglonal Industry Mix and the Business Cycle," New England. Economic Review, July-August, 1978.

Dav1s, Steven. "Allocative Disturbances and Specific Capital in Real Business Cycle Theorles." Amertcan Economlc Revlew, May 1987.

Dunne, Timothy, Mark J. Roberts, and Larry Samuelson. "Planet Turnover and Gross Employment Flows in the U.S. Manufacturing Sector." Journal of Labor Economics, January 1989.

Evans, Dav1d. "Tests of Alternatlve Theorles of Flrm Growth," Journal of Polltical Economy, August 1987.

Freeman, Richard. "Flxed-Coefflclent and Manpower Requirement Models: A Synthes1s" In R. Ehrenberg ed. Research In Labor Economics, Volume 1, 1977.

Gordon, Robert J. "Inflation, Flextble Exchange Rates, and the Natural Rate of Unemployment." In Martin Bally ed. Workers, Jobs and Inflation. Brookings Institution, 1982 . 
Ha11, Robert. "Why is the Unemployment Rate so High at Full Employment?" Brookings Papers on Economic Activity, 1970.

Holzer, Harry, Katz, Larry and Alan Krueger. "Job Queues and Wage Rates: Evidence From the Minimum Wage and Inter-industry Wage Differences." NBER Working Paper, 1988.

Leonard, Jonathan. "On the Slze Distribution of Employment and Establishments." NBER Working Paper No. 1951, 1986.

Leorard, Jonathan. "In the Wrong Place, At the Wrong Time: The Extent of Frictional and Structural Unemployment," In Kevin Lang and Jonathan Leonard, eds. Unemployment and the Structure of Labor Markets. 1987.

Lilien, David. "Sectoral Shifts and Cyclical Unemployment." Journal of Political Economy. fuly, 1982.

Long, John and Charles Plosser. "Real Business Cycles." Journal of Political Economy, February 1983.

Lucas, Robert and Edward Prescott. "Equilibrium Search and Unemployment." Journal of Economic Theory, February 1974.

Marston, Stephen. "Two Viess of the Geographic Distribution of Unemployment," Quarterly Journal of Economics, Eebruary 1985.

Mincer, Jacob. "The Economics of Wage Floors." Journal of Political Economy, 1976.

Mitchell, Daniel J.B. Unions, Wages and Inflation. Brookings Institution, 1980.

Murphy, Kevin J. "Unemployment Dispersim tili the Allocative Efflciency of the Labor Market." Journal of Macroeconomics, Fall 1985.

Murphy, Kevin J. and Rlchard Hofler. "Determinants of Geographic Unemployment Rates: A Selectively Pooled-Simultaneous Model." Review of Economics and Statistics, May 1984. 
Murphy, Kevin M. and Robert Topel. "The Evolution of Unemployment in the Unfted States: 1968-1985," NBER Macroeconomics Annua 1, 1987. Nickell, Stephen, "Dynamic Models of Labour Demand." \pm r. O. Ashenfelter and F. Layand ads. Handbook of Labor Economics, North Holland, 1986.

Rones, Philip. "An Analysis of Reglonal Employment Growth, 1973-85," Monthiy Labor Review, July 2986.

Summers, Lawrence. "Why Is The Unemployment Rate High Near Full

Employment?" Brookings Papers on Economic Activity, 1986:2.

Tiler, Richard and Robert Bednarzik. "The Beharior of Kegional Unemploymet: Rates Over Time: Effects of Dispersion and Nationa i Unemployment. Journal of Regional Science, 1985.

Tope i, Robert. "Local Labor Markets." Journal of Political Economy, Jutis 1986 .

United States Bureau of the Census, City and County Data Book, 1983.

Unfted States Department of Labor, Employment and Training Handbook NC. 39. 1983. 